\title{
Komodo Dragon Attacks: The Changing of Human and Environment Relations
}

\author{
Dian Lintang Sudibyo \\ Department of Anthropology, Universitas Gadjah Mada, Indonesia \\ Email: d.lintang.sudibyo@gmail.com
}

\begin{abstract}
This paper discusses the issue of Komodo Dragon attacks on humans from an anthropological perspective. Wild animal attacks are often regarded as a result of human-wildlife ecological conflict. Humans, in their pursuit of economic expansion, often sacrifice the habitat of fauna, resulting in disturbances to food chain stability in the local ecosystem. It has been said that due to the increased difficulty of finding prey as a result, predators turn to humans instead, which is not part of the natural food chain. However, this research (based on observations on Rinca Island, Komodo National Park in 2013) finds that this explanation is not always correct. In the case of Komodo National Park, a conservation area primarily established to secure the availability of Komodo Dragon prey, the fact that there are still cases of dragons attacking humans throws weight against the idea that dragons are merely supplementing their natural diet. Rather, this paper argues that these attacks come as a result of the creation of spaces that changes the human relationship with the natural environment.
\end{abstract}

Keywords: conservation; human-environment relation changes; Komodo Dragon; dragon attacks; ecosystem change

\section{INTRODUCTION}

In early 2017, a Singaporean tourist was attacked by Komodo Dragons (Varanus Komodoensis) (Komodos) while photographing the Dragons eating goat carcasses on Komodo Island, Komodo National Park (KNP $)^{1}$. This was not an isolated incident of wildlife attacking humans in Indonesia, with reports of man-eating pythons in West Sulawesi just a few months earlier. Indonesia Vice online media entitled this phenomenon: "Insiden Pria Dimangsa Piton, Puncak Gunung Es Perebutan Lahan Manusia dan Hewan di Indonesia"2). This statement reflects how wild animal attacks are typically described in the domain of ecological conflict between animals and humans; implying that wildlife and humans are separated by 'natural' and 'social' boundaries. This supports the assumption that human intervention in the ecosystem acts to break down the food chain, which causes predators losing their food sources to perceive humans as prey.
However, this assumption fails to consider why then attacks in protected areas continue. This study focusses on this shortcoming in previous research, aiming to provide an alternative explanation for why attacks occur, using the case the protected area of KNP.

Many attacks have occurred in KNP, an area where Komodos are protected. KNP territory includes territorial water and lands (three larger islands Komodo, Padar, Rinca and several small islands), which located between Sumbawa Island and Flores Island. With the application of strict rules by conservationists to human intervention in the area in order to maintain the natural food chain system, the question remains: why do dragon attacks still occur in the area? This paper provides an alternative perspective to understand this phenomenon.

A national park is a space established officially through regulations to ensure ecosystem sustainability. 
The creation of these territories is mainly based on the fear of environmental damage due to economic activities. In particular, the pattern of economically-driven activities is considered a threat to the sustainability of local ecosystems (Erb, 2012; Kelly, 2011; Ojeda, 2012). Conservation in these areas, therefore, attempts to alter this pattern to be more sustainable. One initiative is the introduction of ecotourism and the integration of the community into that market, utilizing the existing natural beauty in conservation areas as commodities (Paige \& Carrie, 2004; Goodwin, 2002; Kelly, 2011; $\mathrm{Erb}, 2001)$. This can result in the changing of the socioeconomic conditions of the community who is living in the protected area.

The establishment of a protected area changes the human-environment relationship (West, Igoe, \& Brockington, 2006: 264). This cannot be separated from the concept that space is socially created, or what is known as the production of space (Lefebvre, 1991; Smith, 2008). Lefebvre (1991) notes that 'space' does not preexist; space is produced through the dialectics of social relations, actions, ideas and imagination. In this sense, space is perceived as an integral part of social practice, which becomes both a precondition and a result of social practice. Space, therefore, is only being understood in a specific societal context. Furthermore, space is seen not only in terms of its relation to the current state of the social dimension, but also historically in relation to "social constellations, powers, [and] relevant conflicts in every situation" (Schmid, 2008: 29). In the end, space is seen as not just a place where social relations occurred, but where the perception and social relations - with people and environment - are formed.

The concept of production of space helps to explain how the process of protected area establishment impacts human and environmental relations. This paper argues that KNP is a space produced through social practices, values, and ideas of science that are interpreted symbolically and socially by those associated with space. 'They' not only refers to the people living in the national park, but the scientists and government since the colonial era who applied their conceptions about conservation; these conceptions generally being applied in a particular geographical area (see Scott, 1998: 5). The creation of new space demands the application of new rules, which underpin the success of the establishment of space, changing the human relationship with their environment.

This article explains how the creation of space (for environmental conservation) changes the relationship and meaning of the environment to people in several stages. First, the initial idea of a protected area and its implementation by environmentalists and the government. Second, the changes in human relations with nature after the formation of a protected space. Finally, how communities perceived the change of human-environment relations after the presence of conservation. More specifically, the article focuses on how people interpret Komodo attacks beginning after the establishment of the protected area. In explaining these attacks, the analysis of relations focuses on the human-environment relationship. It will be argued that the relationship between human and environment changes when the space, where systems are intertwined, is reproduced through the ideas and values of experts, and as a result, wild animal attacks against humans were not always the result of the loss of the prey, but occurred as the result of space creation that altered human and environmental relations. Utilising ethnographic data from Rinca Island, KNP collected in 2013, it is proposed that wild animal attacks on humans can be explained through examination of changes to the human-environment relationship. This is converse to the commonly adopted frame of ecological conflict.

\section{THE INTERPRETATION OF KOMODO ATTACKS}

Pak Sidiq (a local resident) provided insight into Rinca Island's relationship with the Komodos. While The Island is the natural habitat of the Komodo, he explained that historically they weren't known to appear in human settlements; rather, remaining in the forest, far away from human inhabitants. People used to see them only when they went into the forest. Pak Sidiq was not sure exactly when Komodos began to appear in their settlement. As far as he could remember, their appearance started since KNP was created (more than three decades ago).

Hunting activities have been banned since the establishment of KNP. This policy aims to protect Komodos from extinction. Komodos were not hunted animals, but their prey (such as deer and buffalo) were. To protect Komodos, conservationists and the government created an area for biodiversity protection. Through the protected area, conservationists aimed to protect the dragons by way of maintaining their habitat and ecosystem. The reason for this expanded approach was because conservationists feared that there would be an imbalance in competition between humans and dragons, threatening the Komodo population as the availability of prey declined, being out-hunted by the humans.

Before being established as a protected area, the island used to be a deer hunting location (see Barnard, 2011; Blower et al.: 1977). In the 1970s, Pak Sidiq was 
one of these deer hunters. At that time, there were many dogs that roam the island, which, in addition to guarding the gardens against monkey attacks, were used by hunters to sniff-out and herd deer into traps. When the deer had been caught, hunters would not bring the whole body of captured animals to home, but rather, take the meat only. The bones, skin, organs and the head of the deer were left behind. According to Pak Sidiq, in the eyes of the hunters, bringing the meat home and leaving the unwanted parts was seen as an act of food sharing with Komodos. This was perceived to create a balance, where, since the dragons were fed, they had no need to venture into the village. As Sidiq explains:

"It is hard for dragons to find their own prey, [leading] even [to] dragons eat the young dragon after they hatched. Hunters were feeding dragons from the discarded animal parts. Now after hunting was forbidden, dragons are often seen in the village, because they smell the food from the settlements"

According to Pak Sidiq, as there were no longer parts of the prey being left by hunters, this led the dragons to search further afoot for food, ending up in the villages. Komodos are able to detect the scent of prey from a distance of 4 to 9 kilometers using their tongue. Rinca, being a fishing village with the smell of drying fish in the air, as well as the presence of livestock, made an obvious substitute and subsequent target for Komodos. There were several cases of dragons attacking livestock, such as goats.

Among the people in Rinca, Komodos are known as lazy, evil animals. To the people, they do not appear active, tending to stay silent in one place. They eat animal carcasses or reptile and poultry eggs, and even their own hatchlings. With this reputation, hunters saw it that the dragons would be happy to receive the left-over body parts from human hunting, of which the animals were their natural prey. Knowing hunters would leave the food, the dragons appeared to become accustomed, lurking in the woods waiting for the scraps, rather coming out and moving around to look for prey.

The story told by Pak Sidiq raises further questions, meriting further investigation. Underpinning this is the idea that when a space is reformed, and its new rules are applied to a society that has long been intertwined with the surrounding environment, it will change the relationship between humans and their environment. The story of Pak Sidiq becomes the background to inquiry on the impact of human-environment relation changes on Rinca Island. This explanation lays the foundation for the argument that Komodo attacks on humans were not sufficiently explained in the mere context of ecological conflict. In this context, humans and animals alike must be seen as agents in a mutual process of forming relations in a social space. Therefore, to understand, inquiry must start with changes to human relations with the environment resulting over the transition from colonial time to independence, and to the establishment of KNP and the present day.

\section{IMPLEMENTATION OF REGULATION}

KNP is a geographical space that was created to preserve the ecosystem through conservation. The process was strengthened by regulation, enabling a mode of territory control (Peluso and Lund, 2011). Its establishment and associated protective measures were based on the recommendations of experts utilising scientific methods of analysis (Cribb, 2007), who determined the actions that should be taken to produce specifically intended outcomes (Li, 2012). Since the implementation of this regulation, everyone living within the protected area has been obligated to observe conservation rules. Obedience to these rules has slowly (yet surely) changed the knowledge and relationship of the population towards the environment.

The establishment of KNP can be traced back to the Dutch colonial period. At that time, the idea of creating a wildlife sanctuary for the dragons' habitat was recommended by J.K de Jong in 1929 as a result of research conducted after friction between environmental institutions and scientists of Western countries and the colonial government over the limiting of access to the dragons (Barnard, 2011). However, before this, the first concerted effort to investigate Komodo dragons was by J.K.H van Steyn van Hensbroek, an administrator of Dutch East Indies in Manggarai. He pursued determination of the existence of giant lizards called 'buaya darat' that, according to local rumour, could grow up to seven meters in length. His curiosity led him to conduct a small survey to determine the merit of these claims. Hensbroek did indeed find that these monsters existed, but also that they were not as massive as he had heard. Following this, Hensbroek sent two meters of dragon skin to Peter Ouwens, the Director of Zoological Museum and Bogor Botanical Gardens. Based on Hensbroek's findings, in 1912 Ouwens wrote the very first article about the newly recorded species, which he named Veranus Komodoensis. The article caught the attention of explorers and scientists alike, who too then went in search of the dragons (Barnard, 2009: 42).

Komodo Dragons became more well-known upon 
the publication of 'Dragon Lizards of Komodo', a book authored by American adventurer William Douglas Burden based on his expedition to Komodo Island. This book again changed the image of the creatures, from merely a giant lizard, to a 'dragon' - a legendary and exotic animal inhabiting an isolated island. When Burden returned to America, he brought back two live dragons for the Bronx Zoo in New York. On their first day of exhibition, the pair drew considerable public attention; the zoo receiving 38,000 visitors on that day alone (Barnard, 2011: 97).

Afraid of what this level of public interest in the dragons could bring about, the Dutch East Indies Government applied rules to limit access to wild Komodos. This action brought about controversy with Western scientists and institutions that were interested in the dragon, leading to calls for the government to revise regulations to allow them to obtain specimens. In order to resolve the conflict, K.W. Dammerman - the director of Buitenzorg, responsible for the natural protection of the Dutch East Indies - assigned de Jong to study and collect new data about Komodos in 1937 (Barnard, 2011).

Following this, another study was undertaken to determine if the existing regulations were based on scientific accuracy or assumptions, looking at things such as the number of dragons in the habitat. This became the basis of regulatory direction, when it was concluded that dragons were threatened (Barnard, 2011: 119). De Jong found that while the number of dragons was quite high, their vulnerability arose from hunters hunting the dragons' natural prey, such as deer. He suggested that dragons being caught for scientific interest or museum needs was not a key concern. However, dragon captures had to be limited to 15 - 20 every five years. In addition, he argued that the most appropriate measure to ensure protection of the Komodo was to build a wildlife sanctuary.

According to Barnard (2011) de Jong's proposal for a wildlife sanctuary became 'the basis for all future plans for preserving and protecting the animal in its natural environment' (Barnard, 2011: 119); a level or form of protection that unlike and above conventional endangered animals protections for the time. In 1924, the Colonial government established rules against poaching; with local communities being regarded as the main threat to vulnerable wildlife (such as rhinos or bird of paradise) (Cribb, 2007). De Jong's recommendation for a wildlife sanctuary was to establish a protected area that conserves the ecosystem in its entirety. According to de Jong, deer hunting posed the greatest threat to the existence of Komodos (Barnard, 2011: 119-120), and so, measures were to include the protection of not only the threatened animals themselves but also their food supply. Achieving this meant that the spatial scale of the protection area needed to be based on the existing ecosystem.

On a visit by de Jong to Loh Buaya on Rinca Island in 1929, a place known for lizard capture, he was unable to secure a specimen, and found no sign Komodo activity, which was linked a massive deer hunt (that's scale and methods were labelled as destructive) that occurred only a month and a half before his arrival (Barnard, 2011: 121). Other than de Jong, a Hungarian Anthropologist and filmmaker, Paul Fejos, also reported similar things. Witnessing the hunting, he remarked that "the vandal method of burning up the hectares of vegetation to chase two or three deer to the seashores, is undoubtedly causing the death of many of the varanes, who perish in the fire on the mountainsides" (Barnard, 2011: 121-122).

In order to provide the greatest assurance against the human threat to wildlife, according to de Jong, the most appropriate area for the wildlife sanctuary was the southern peninsula of Rinca Island. This recommendation was based on several reasons: 1) that the area was largely uninhabited; 2) it is difficult to access; and 3) there was little foreseeable economic loss for the community (ibid, 2011: 120). With this, the directors of economic affairs, home affairs, and the Botanical Gardens came up with a number of options for moving the proposal forward, including: 1) moving and compensating the people living there; 2) involving the local community in controlling and restricting access to the island; or 3) establish a wildlife reserve in only some parts of Komodo and Rinca Islands. All things considered, the Dutch authority chose the third option as it was seen as the easiest to implement; agreeing not to displace the local populations (ibid, 2011: 120). Finally, in 1938 the lieutenant-governor of Manggarai inaugurated the wildlife protection areas surrounding Padar Island, and parts of Komodo and Rinca Island (Blower et al. 1977: 6).

As mentioned earlier, it was considered that conservation was to focus on protection of the Komodos' food supply, of which deer were key. In establishment of the protected areas, regulations to limit hunting were also applied to address various issues. First, this prohibited hunting by non-residents of the islands of Komodo and Rinca (especially people from Sumbawa and Flores), with locals retaining the right to hunt in their native territory ${ }^{3)}$. This appears to have been controversial among hunter populations, as can be seen in a Flores hunter's opinion:

"parties of hunters from Flores and Sumbawa have gone to Komodo to catch deer for as long as I can remember $[\ldots]$. But now it is forbidden, and only 
the people of Komodo may hunt there. Why? [...] The government wants to keep the deer for the dragons. They say that if we go to Komodo and catch deer, the dragons won't have enough to eat. Land crocodile [...] useless beast! I'd rather have one fat deer than all the dragons in Komodo"

$$
\text { - Hadji Soepoe (Barnard 2011: 123) }
$$

To limit the hunting activities the Manggarai local government imposed significant financial penalties for those caught violating; including, 250 guilders ${ }^{4)}$ for dragon hunters ${ }^{5}$ and 10 guilders for deer and pig hunters.

On top of them being directly detrimental to deer populations (owing to over-hunting and also as many were lost to fire as a result of "vandal" hunting methods), hunting methods common in these areas until this time were also considered damaging to the ecosystem. Consequently, while locals retained the right to hunt, they were required to opt for less destructive hunting methods. Despite the various rules implemented to limit hunting activities, however, much of the previous hunting practices continued for the remainder of the colonial period. The situation perpetuated after independence, as the Indonesian government reorganized and continued regional protection policies that had been established during the colonial period.

Despite the ongoing threats to the ecosystem, it wasn't until the 1970s when efforts were made to upgrade the status of the protected areas, from wildlife sanctuary to national park. National park status, while like that of wildlife sanctuaries that emphasized the protection of flora and fauna in their ecosystem, additionally (albeit in a limited capacity) meant restricting the use of space for community activities. A research-based approach was taken in the process, with The Government, through the General Directorate of Forestry, being guided by a management plan proposal written by Blower et al. (1977).

In essence, their conclusions followed the same vein as those recommended by de Jong 40 years earlier. Departure from de Jong was perhaps most notable with Blower et al.'s recommendation for the total prohibition of hunting within all area, as well as the eradication of dogs to limit hunters' ability to find wildlife. In all, Blower et al. (1977: 22) outlined seven key requirements for the establishment of Komodo National Park:

A. Establishment of a National Park to include the existing Komodo and Padar/Rinca reserves, together with the adjoining northern portion of Rinca and surrounding smaller islands (total area approximately 59,00 ha). The seaward boundary should be $1000 \mathrm{~m}$. from shore but should also enclose the straits between the main islands.

B. The two villages of Komodo and Rinca should be included as enclaves whitin the National Park, but three smaller and more recent settlements of Kerora, Tambora and Loh Baru on the eastern coast of Rinca should be removed and resettled elsewhere

C. Development, including airstrip, visitor accommodation and other facilities, should be confined to an Intensive-Use Zone of not more than 200-300 ha. in the Loh Liang area on the East Cost of Komodo. The northern portions of both Komodo and Rinca should be Wilderness Zones where visitors would be permitted subject to certain conditions, and the southern parts of both conditions, and the southern parts of both islands - also Padar Gili Motang - Sanctuary Zones with no access except for purposes of management or scientific research;

D. Habitat management should be aimed at maintaining optimum habitat for varanus komodoensis and its prey species (principally rusa, Cervus Timorensis). Pending availability of research data on which to base management policies, this should include controlled early burning with a view to maintenance of present proportions of savannah grassland and forest

E. Dogs are one of the most serious threats to Varanus Komodoensis and should be prohibited. Feral dogs on Padar and elsewhere should be eradicated as soon as possible

F. The National Park headquarters, with Warden in charge, should be established at Loh Liang (Intensive Use Zone) on Komodo, with guard posts elsewhere to ensure effective law enforcement, and especially to prevent poaching of rusa by people from Flores and other island

G. A resident ecologist should be included in the Park Staff, and management orientated research should be encouraged especially on grass-burning and trends in relations to vegetation changes, also studies of the ecology of Varanus Komodoensis, the mound-building megapode, and on research movements of marine mammals and fish.

Two other significant points in the transition to a national park were related to necessary changes to the community's relationship with the environment in the park area. First, was zonation to differentiate areas by 
function and usability. The second, was the resettlement of inhabitants from the three smaller villages of Loh Baru, Tambora and Kerora ${ }^{6}$, to the larger Komodo and Rinca villages.

\section{THE CONSEQUENCES OF RULES IMPLEMENTED}

In 1977, there were four settlements on Rinca Island Rinca, Kerora, Tambora, and Loh Baru (see table 1 ). The people established two distinct areas in these settlements; the most significant and established parts for living, social relations, ceremony, etc. was the village. The village was marked with graves and mosques, while the huts were established outside the village area, close to where the people performed economic activities. There are two main economic activities that follow an annual seasonal cycle, fishing and farming seasons. Fishing happens during the dry season, while farming typically starts by the beginning of the raining season. The dry season is the period where lure fish (engraulidae) are in the bay. Once the fishing season ends, the farming season begins. Though the transition may depend on rainfall, as farming activities depend on it as their only water source. As farming and fishing activities were located far from the villages, the people build huts to serve as housing while at each activity site. The people would stay in the huts for months at a time, rarely returning to their village through these periods. This had become their way of life.

Table 1. Population of Komodo National Park area in 1977.

\begin{tabular}{|c|c|}
\hline & Population \\
\hline \multicolumn{2}{|l|}{ Komodo Island } \\
\hline Komodo Village & 529 \\
\hline \multicolumn{2}{|l|}{ Pulau Rinca } \\
\hline Rinca Village & 460 \\
\hline Keroro Village & 225 \\
\hline Tambora Village & 28 \\
\hline Loh Baru Village & 43 \\
\hline Pulau Rinca total & 756 \\
\hline TOTAL & 1285 \\
\hline
\end{tabular}

Source: Blower et al. (1977: 22)

However, the implementation of protected area rules also meant that certain economic activities were (and remain) significantly limited. One significant disturbance to these activities has been the implementation of zonation, which geographically limits places and space for specific activities. Zonation was intended to ensure the establishment of managed spaces, strictly in accordance with said zones' designated use (Hermawan et al., 2014: 28). Zonation was aimed to achieve the national park objectives actioned in laws 5/1990 and 41/1999, addressing "natural conservation areas that have native ecosystems managed by zonation systems, and utilized for research, science, education, cultivation, tourism and recreation purposes" (ibid., 2014: 29). At the same time, inhabitants were restricted from settling in areas not intended for human activities; of which, the sites of their previous settlements were. These created significant shifts in their livelihood and economic activity patterns.

In overall terms, however, no aspects were more impacted than farming and hunting. New opportunities have coincided in fishing and tourism, however. Fishing experienced significant changes in the 1990s when modern fishing gear (such as engine-driven boats and manufactured fishing nets) were introduced. With this modern equipment, their capabilities to fish were expanded, seemingly exponentially when compared with previous means. They could move much faster and further, and with greater catching capabilities. Despite their increased ability to rely on fishing as an economic staple, this was, however, significant in its redefinition of the human-environmental relationship and local knowledge.

Farming has not been so fortunate in its transition through the introduction of national park rules. The change this has created is obvious upon the recollection of collective memories by remaining inhabitants of those times. They can still easily point out who each of the fields belonged to. Their knowledge of the fields' borders follows neatly arranged Kedondo trees, who's straight rows acted as territorial boundary markers. Though, besides the displacement from the land and the limiting of farming activities, the recollections of life at these plots was linked to another shift from pre-national park practices and life of the people. In these areas, dogs were kept by farmers as they were seen to have good instinct, a strong sense of smell, and to serve as companions. The dogs were protectors of the farmers and their fields, with the ability to detect threats, such as the sudden appearance of wild animals. Beyond companionship and protection, the dogs also played an important role for hunters, which the locals had practices for a long time. In 1929 de Jong reported about deer hunters using dogs and grass burning as strategies to herd the deer into traps and dead-ends (Barnard, 2011: 121). In the 1970s to 80s hunting with 
the help of dogs was still practised. According to one of the former hunters, hunting deer was easier prior to the area's reclassification as a national park, in 1980.

In addition to hunting dogs, stray dogs spread out around Komodo, Rinca and Padar island, also threatening Komodos. Dogs are not a native animal in the area, originally being brought by hunters from Flores and Sumbawa, then bred and spread throughout the islands. The increasing dog population became unmanageable and many were left stray. The most threatening was the feral dogs on the uninhabited island of Padar. People said that as a result of the rampant population growth and lack of control and the subsequent disruption to the peoples' activities, the dogs were moved from Komodo Island by the people. These dogs survived by preying on deer, rats, reptiles and poultry eggs (including those of the Komodo Dragons), and even young dragons (Blower et al. 1977: 20). Subsequently, the dogs were labelled as significant contributors to the threat and decline of Komodo existence. Thus, according to conservationists, dogs needed to be exterminated. The strategy to eradicate the dogs as per the KNP establishment proposal in 1980, states that:

"The most important requirement is to protect the ora (komodo dragon) and its principal prey species, the rusa ${ }^{[7]}$, against hunting or harassment by both man and dogs [...] Feral dogs in the Park area should be considered as pests and systematically eradicated by hunting and trapping, avoiding the use of poison or other methods which might harm the ora" (Blower et al., 1977: 38-39).

Since the mass capture, collection and euthanisation of the dogs that roamed the area, the people no longer keep dogs. In this respect, the conservation rules appear to have worked, despite the reason of the people being largely based on the fear of penalties if they caught possessing them, and not the perceived benefits or necessity of conservation or preservation efforts. To this day, since the implementation of the rule, dogs are reportedly not found in KNP.

The removal of dogs altered the pattern of local activity radically. Since their domestication thousands of years ago, dogs have played an important role in human socio-economic development. Dogs not only supported hunting activities but warned people of threats, such as wild animals or others trying to attack their settlement (Harari, 2014: 35). The benefits of their relationship with the dogs for hunting-gathering communities were particularly beneficial (even symbiotic). This was evident for the locals of Komodo and Rinca islands too, where dogs were more than just a hunting tool. They were considered companions and helped in other aspects, such as keeping farmland safe from monkey and wild boar attacks, and as an early warning system against threats approaching general areas of human activity. From a conservationist stand-point, however, the human-dog relationship was perceived primarily as a threat, and too great to allow in any capacity.

Following these changes (in the transition from wildlife sanctuary to national park status), people were forced into new relationships with the environment; at the same time profoundly affecting their knowledge. These changes are also argued to have contributed to the rise of Komodo attacks on humans.

\section{KOMODO DRAGONS ATTACKS: HUMAN- ENVIRONMENT RELATION CHANGES}

Implementation of conservation values has been perceived as one of the reasons for the emergence of Komodo Dragon attacks on humans. The people of Rinca recognise that there had never been a case of a Komodo attaching a human before restrictions on hunting were introduced. Not only do they note that there were no cases of attacks, but even to sight the Komodos, inhabitants needed to venture into the forest. Now, the dragons are often seen coming to village areas.

On Komodo Island, folklore tells of dragonhuman relations. Belief holds it that people and Komodos (traditionally known as ora) have a blood relationship called sebae (brother), and that their ancestor and dragons were born from the same womb. This comes from the tale of princess Putri Naga of Komodo Island. Legend has it that the princess married a man named Majo, and that she gave birth to twins. Unfortunately, one of the twins was said to have the shape of a lizard. While one of the twins was named Gerong, the one said to resemble a lizard was named Ora. As her son (Ora) didn't look like a human, Putri Naga secretly took and left him in the forest, meaning Gerong wouldn't know about his twin brother.

After years had passed and Gerong reached adolescence, he was one-day hunting deer in the forest. At some point, he spotted a deer, firing arrows and successfully bringing the animal down. On Gerong's approach of the dying deer (to finish it off and prepare it carcass to take back to the village), he was shocked with the sudden appearance of a giant lizard, which was trying to take the immobilised and dying animal. Unwilling to lose his capture, Gerong prepared a spear to challenge the lizard. However, upon attempting to attack the beast, his mother suddenly appeared, trying to hold Gerong back his 
intended charge. She explained to the boy that the lizard was his own twin brother, and hoped that Gerong would treat the lizard like her own brother and be willing to share the food with it. People said that after the incident, Komodo Island inhabitants widely regarded the lizard as a brother, leading to the traditional hunting and remainsharing practices common until outside intervention in the colonial and early independence eras.

The moral of the story could be perceived as a model to describe the human-dragon relationship in the past, and their awareness of the importance of foodsharing between humans and dragons. While the story does not explicitly highlight the objective of food sharing, it can be interpreted as human effort to treat dragons appropriately as they are not perceived as an enemy. The logic of the story was similar to that told by Pak Sidiq about hunters sharing food with the dragons, and that relation keeping the Komodos from coming to the villages in search of food.

The lessons of the story appear rational when considering the dragons' behaviour. Komodos are predators that hunt deer, monkey, wild boar, buffalo and reptiles (including their own and other young dragons). Using their tongue, Komodos have the ability to detect and smell prey and carrion as far as 10 kilometers away. It can eat up to $80 \%$ of its body weight for each meal and survive with only 12 meals a year, needing to feed roughly only once a month. After eating, Komodos will stay in a sunny place to aid in the process of digestion. As well, Komodos are rarely seen moving. These behaviours led to the earlier-mentioned view of local people that the dragons are lazy and just waiting food from hunters. Modern analysis of them shows, however, that it is actually due to the dragons' slow metabolism allowing them to restrain eating for long periods, allowing an easy transition to becoming creatures of opportunity.

Irrespective, after the implementation of hunting restriction marks when Komodos are thought to have started to enter villages. According to locals, it is because they could not find the meals that they had become accustomed to, usually left by hunters. Field research for this study in Rinca Village found evidence to support this. In the first days of my arrival on Rinca, cautionary warnings of Komodos were commonly expressed by locals when going to bathe or collect water. This was because the water source is about 200 meters away from the settlement, and Komodos are believed to usually hide in the thickets and were sighted several times around the water source. The community's anxiety is not without reason. Since KNP was established, there were several incidents of Komodo attacks.
In Rinca Village itself, there have been at least three cases of Komodos attacking humans. The first was a seven-year-old boy who died in 1997. At that time he was sitting on the steps of his family house. An eyewitness said, he was swinging his legs from the stairs, and that it appeared to be the boy's foot movement that attracted the dragon's attention. When the dragon ambushed it tore open the victim's stomach; injuries the boy succumb to and died. Villagers blamed park officers stationed at Rinca for not ensuring adequate feeding of the dragons, and as a result, hunting for anything ${ }^{8}$.

Another attack happened to a middle-aged woman when she was in a garden nearby her house. Fortunately, she was aware of the dragon's presence in time and was able to avoid fatal injury by quickly taking off her sarong and throwing it on the head of the dragon. According to accounts, the Komodo proceeded to flick its head around trying to get the sarong off that had blocked its vision. Meanwhile, the woman was able to seek refuge by climbing up a nearby coconut tree, where she was able to shout for help. Luckily someone heard her shouting, and responders were able to expel the dragons.

The last incident involved an elderly woman in 2013 while she was making a broomstick. Dragons appeared behind her and pounced on her hand. People believed that it was the movement of the lady's hands slashing the leaves that attracted the dragons' attention. Fortunately, the attack was not fatal, with the victim able to get away and seek medical attention for injuries to her arm at the hospital in Labuan Bajo (around 2-3 hour away by boat, on the mainland of Flores).

Another of the reasons alleged by locals as to why the incidents were occurring was because of the lack of early warning from dogs. Though dogs could also become Komodo prey, they have significant advantages over the drags and their human companions. Dogs have, first, a superior sense of smell, and secondly, instincts that allow them to detect certain dangers approaching, both, alerting them well-before humans would be able to sense the threat. The barking of the dogs would alert of the situation, while people would be able to respond timely and adequately to repel or escape the threat. A real-life occurrence of this, recorded in an interview with a resident on Rinca Island, who confirmed that their dogs would bark when Komodos approach.

Today, the system of warning relies on communication between people. If someone becomes aware of the presence of a Komodo, they immediately identify this through shouting. However, the human ability to sense the presence of Komodos is limited. Komodos hunt their prey by creeping slowly and hiding 
in and around thicket. This may see humans much closer to the dragons before being aware they are there, and with a speed of up to $20 \mathrm{~km}$ per hours means the human odds of getting away are dramatically lower. The Komodos' ability to successfully attack at close range is strengthened by their sharp claws and strong bite. Thus, to deal with the threat of attacks, an early warning system for humans to alert of the presence of Komodos (such as the dogs of the past) is critical.

Tracing of historical condition of people in KNP shows that Komodo Dragon attacks on humans stem from human-environment relationship changes. The eradication of dogs is an important factor that supports this. Besides them being able to be used by people to help them carry out their economic activities, dogs could be an effective instrument in early warnings against outsiders or wild animals alike.

\section{CONCLUSION}

This paper examines the idea of wild animal attacks on humans. It is argued that wild animal attacks on humans can be explained as a result of space changes, which subsequently alters the human-environment relationship. Using the notion of production space, introduced by Lefebvre (1991), this article explains how inhabitants understand the dragon attacks, which are largely attributed to hunting bans that began when conservation spaces were formed.

It appears clear that the attacks are not simply the result of ecological conflict as is typically explained when it comes to wild animal attacks. Rather, the case of Komodo attacks in KNP is an example of where the establishment of conservation space did not provide forest-dwelling Komodos with adequate prey, and that response measures based in environmentalist assumptions did not bring closure to the ecological conflict of human and animal. Instead, the implementation of conservation enhanced the possibility of komodo attacks.

The conservation endeavour was to limit the mobility of land activities, eliminating hunting and eradicate of dogs in the process. The extermination of dogs was considered a critical impact. Hunting and cultivating societies benefitted greatly from the dog's natural ability to support their activities, sniffing out animals for hunting and keeping wild animals from the field and settlements. The ability of dogs to detect threats also served as an early warning system for humans. The eradication of dogs, put simply, led to the possibility of dragon attacks on humans being even greater.

This does not imply that wild animal attacks on humans being attributed to ecological conflict are wrong outright. Instead, it provides an alternative explanation and perspective help us understand these incidents and the reasons behind their prevalence. However, in this case, if the problem is truly the result of ecological conflict, why did the allocation of space for Komodos see the continuation of attacks on humans and their emergence in built-up areas? This paper provides another perspective, showing that the attacks are a consequence of space production that changes the relationship between humans and their environment.

\section{ACKNOWLEDGEMENT}

This research was made possible by the In Search of Balance (ISB) grant, I received in 2013. This facilitated the collaboration of Gadjah Mada University and University of Agder. I am deeply indebted to Thomas Borgert (Swinburne University of Technology) for his comments and language editing and Nindyo Budi Kumoro (University of Brawijaya) who commented on earlier draft of this article.

\section{ENDNOTES}

1) https://kumparan.com/salmah-muslimah/mengapa-turissingapura-diserang-komodo-saat-memotret

2) https://www.vice.com/id_id/article/gvekv7/insidenpria-dimangsa-piton-puncak-gunung-es-perebutan-lahanmanusia-dan-hewan-di-indonesia

3) It is not clear why natives were allowed to continue hunting. This may, however, be related to the relatively small populations. In 1930, for instance, Komodo Island was home to only 143 inhabitant (Barnard, 2011: 120).

4) 'Guiders' were the currency at the time

5) The dragon hunters is mainly carried out by Chinese people who take their body parts for medicine treatment. In Barnard's note (2011) the numbers were not as many as deer hunters and swine

6) Of the three mentioned, Kerora still remains today, while the populations of Loh Baru and Tambora have relocated to Rinca Village (see table 1 for 1977 population figures)

7) A Southeast Asian native deer genus

8) http://www.viva.co.id/indepth/wawancara/263857-sayadiancam-parang-gara-gara-komodo

\section{REFERENCES}

Barnard, Timothy P. (2011). Protecting The Dragon: Dutch Attempts at Limiting Access to Komodo Lizards in the 1920s and 1930s. Indonesia, 92, 97-124. http:// cip.cornell.edu/seap.indo/1319755163 
Blower, J.H., der Zon, A.P.M Van., Mulyana, Yaya (1977). Proposed Komodo National Park: Management Plan 1978-1982. Bogor: Nature Conservation dan Wildlife Management Project dan Agricultural Organisation of the United Nations, Direktorat Jendral Kehutan.

Cribb, Robert (2007). Conservation in Colonial Indonesia. Interventions, 9(1), 49-61. https://doi. org/10.1080/13698010601173817

Erb, Maribeth (2001). Ecotourism and Environmental Conservation in Western Flores: Who Benefits? Antropologi Indonesia, 66.

Erb, Maribeth (2012). The Dissonance of Conservation: Environtmentalities and The Environmentalisms of the Poor in Eastern Indonesia. The Raffles Bulletin of Zoology, 25, 11-23.

Goodwin, Harold (2002). Local Community Involvement in Tourism around National Parks: Opportunities and Constraints. Current Issues in Tourism, 5(3-4), 338360. DOI: 10.1080/13683500208667928.

Harari, Yuval Noah (2016). Sapiens: A Brief History of Humankind. London: Vintage Publishing

Hermawan, M. Taufik Tri, dkk.(2014). Pengelolaan Kawasan Konservasi. Yogyakarta: Gadjah Mada University Press.

James, C. Scott (1998). Seeing Like a State. Yale University Press.

Kelly, Alice B. (2011). Conservation practice as primitive accumulation. The Journal of Peasant Studies, 38(4), 683-701. DOI: 10.1080/03066150.2011.607695

Kanuru, Jo (2011, 14 November). "Saya Diancam Parang Gara-Gara Komodo”. Viva.co.id, https://www.viva. co.id/arsip/263857-saya-diancam-parang-gara-garakomodo

Lefebvre, Henri (1991). The Production of Space. Oxford dan Cambridge: Basil Blackwell.

Li, Tania Murray (2012). The Will to Improve: Perencanaan, Kekuasaan, dan Pembangunan di Indonesia. Jakarta: Marjin Kiri.
Muslimah, Salmah (2017, 4 Mei). Mengapa Turis Singapura Diserang Komodo Saat Memotret? KumparanNEWS, https://kumparan.com/salmah-muslimah/mengapaturis-singapura-diserang-komodo-saat-memotret

Ojeda, Diana (2012). Green Pretexts: Ecotourism, Neoliberal Conservation, and Land Grabbing in Tayrona National Natural Park, Colombia. The Journal Peasant Studies, 39(2), 357-375. DOI: 10.1080/030 66150.2012 .658777$.

Peluso, Lee N., Lund, Christian (2012). New Frontiers of Land Control: Introduction. Journal of Peasant Studies, 38(4), 667-681. https://doi.org/10.1080/03 066150.2011 .607692

Renaldi, Adi (2017, 30 March). Insiden Pria Dimangsa Piton, Puncak Gunung Es Perebutan Lahan Manusia dan Hewan di Indoneisa. Vice.com, https://www.vice. com/id_id/article/gvekv7/insiden-pria-dimangsapiton-puncak-gunung-es-perebutan-lahan-manusiadan-hewan-di-indonesia

Schmid, Christian (2008). Henri Lefebvre's Theory of Production of Space: Towards a Three-Dimensional dialectic. In Kanishka Goonewardena et all, eds. Space, Difference, Everyday Life: Reading Henry Lefebvre. New York dan London: Routledge.

Sutton, Mark Q., Anderson, E.N. (2004). Introduction to Cultural Ecology. North America: ALTAMIRA Press.

Smith, Neil (2008). Uneven Development: Nature, Capital, And the Production of Space. Georgia: The University of Georgia Press.

West, P., Carrier, James G. (2004). Ecotourism and Authenticity: Getting Away From It All?. Current Anthropology, 45(4), 483-498. https://doi. org/10.1086/422082

West, P., Igoe, J., Brockington, Dan (2006). Parks and People: The Social Impact of Protected Areas. Annual Review of Antropology, 35, 251-277. 